DOI: $10.20472 / \mathrm{IAC} .2017 .33 .003$

MAISOUN ALZANKAWI

The Public Authority for Applied Education and Training, Kuwait

\title{
KUWAITI UNDERGRADUATE PROBLEMS WITH COHESION IN EFL WRITING
}

\begin{abstract}
:
This study is designed to investigate the present situations of Kuwaiti undergraduate students of English, and their attitudes towards the writing process. Specifically, the study aimed to address the following research questions: (1) What are the characteristics of the texts produced by Kuwaiti undergraduate students in terms of cohesion and quality? (2) Is there a relationship between cohesive devices' measures and text evaluation scores? The main objective of the researcher was to concentrate on dealing with the macro level cohesive devices in students' descriptive English writing. The participants in this study were 128 Kuwaiti college students of English in the first and second year of study at Kuwait University, College of Arts. A mixed methods design of both qualitative and quantitative research methodology was utilized to analyze the participants' written texts. In addition, the framework of Halliday and Hasan's (1976) theory of cohesion was used to analyze the written products of the participants. The findings revealed that there was a notable difference in the students' use of cohesive devices in terms of frequency. Students overused certain types of cohesive devices (reference, conjunction, and lexical) while neglecting to use the others (substitution and ellipsis). The analysis also revealed that the correlation coefficient between writing scores and reference cohesive device is positive and statistically significant, since only the reference cohesive device was highly correlated with score.
\end{abstract}

\section{Keywords:}

EFL writing, cohesion, descriptive writing, writing quality

JEL Classification: 129 


\section{Introduction}

In many Arab countries, including Kuwait, the educational systems emphasize writing for taking tests. In this respect, some studies in the Arab world were conducted offering different approaches and remedial programmes to overcome the writing problems and to develop students' EFL writing skills (Al-Hibir \& Al-Taha, 1992). In relation to the EFL students, many studies pointed that cohesion constitutes a serious problem to Arab students (Ahmed, 2010). However, to the best of the researcher's knowledge, there is a lack of Kuwaiti studies that tackled cohesion in students' English writing. Hence, the current study is exploring the cohesion problems that Kuwaiti college students of English face in their writing process so that course designers in Kuwait (or in any other Arab country) take the findings and results of the current study into consideration when designing writing curricula for students of similar education and background.

\section{Literature}

The term "writing" is defined as the most significant cultural accomplishments of human beings. It allows us to record and convey information and stories beyond the immediate moment and to communicate at a distance, either at a distant place or at a distant time (Rogers, 2005). Chakraverty and Gautum (2000) believes that writing is a reflective activity that requires enough time to think about the specific topic and to analyze and classify any background knowledge. Lately, writing is seen as a complex activity and a social act which reflects the writer's communicative skills which is difficult to develop and learn, especially in an EFL context (Shokrpour \& Fallahzadeh 2007). Moreover, Kharma and Hajjaj (1989) define writing in reference to the content or literary style that is used in various senses. According to Kharma and Hajjaj, writing is also defined as the use of graphic marks to represent specific linguistic utterances. Writing is not language but does represent language, because language is a complex system residing in our brain which allows us produce and interpret utterances. Thus, writing involves making an utterance visible.

\section{The Importance of EFL/ESL Writing}

EFL/ESL writing has always been considered an important skill in teaching and learning. According to Rao (2007), EFL writing is useful in two respects: First, it motivates students' thinking, organizing ideas, developing their ability to summarize, analyze and criticize. Second, it strengthens students' learning thinking and reflecting on the English language. In addition, Fageeh (2003) stated that writing is a complex process that requires a great deal of effort to learn, since it has to be learned by exposure and in conscious manner. Furthermore, writing an acceptable English academic text is the most challenging task that international students face in English (Taher, 1990). Many researchers have investigated 
developing the skill of writing. The writing skill is one of the two productive four language skills. It needs reasonable efforts on the part of the learners and a variety of activities to be included in teaching material to enable learners to practice writing effectively (Abd El.Motaal, 2001).

The importance of writing in our public and private lives is enormous. Without writing, life is almost unimaginable for much of the world today. Once we humans possess writing, we regularly turn it into a social object. Most often it has been associated with education and intellectually loftier portions of society. Not infrequently, societies have spoken one dialect or language and written another. Major struggles have resulted for and against changes in the way writing is done in language (Rogers, 2005).

In relation to the context of the current study, writing is significant to the learning of Kuwaiti college students of English, because it facilitates students' acquisition of the basic study skills needed for understanding what they study and express themselves in their own words through writing. In addition, competence in writing helps students pass all their academic courses successfully, and prepare them to acquire a standard level of English proficiency that meets the job demands as well as those of higher Education in English.

\section{Halliday and Hasan's Cohesion Taxonomy}

Cohesion has been widely accepted for textual analysis, as it refers to the grammatical and lexical elements on the surface of a text which can form connections between parts of the text (Connor, 1996). In relation to ESL/EFL writing cohesion, many researchers agree that cohesion, on the macro level, is related to linking ideas, whereas on the micro level it is concerned with connecting sentences and phrases (Ahmed, 2010). Many researchers have highlighted the importance of text cohesion, claiming that a text stands as a text by means of cohesion; without cohesion, sentences would be fragmented and would result in a number of unrelated sentences (Hinkel, 2004).

Halliday and Hasan's work on cohesion (1976) laid the bases for research in this area. In their classic study of cohesion in English, they defined cohesion as the linguistic devices the writer used to generate a textual continuum. Additionally, they define the term cohesion as "the concept of cohesion is a semantic one; it refers to relations of meaning that exist within the text, and that defines it as a text" (Halliday \& Hassan, 1985, p. 4). Following the publication of Halliday and Hasan's study (1976), language educators and teachers have become interested in the use of cohesive devices within students' written composition. In fact, a number of research studies have been conducted and several researchers have used the outline of cohesion in English presented by Halliday and Hasan. Their work is considered a reference for the analysis of various kinds of cohesive devices (Qaddumi, 1995). Thus, it is important to become familiar with the cohesion taxonomy presented by Halliday and Hasan in 1976. 
Halliday and Hasan (1976) identify five types of cohesion: reference, substitution, ellipsis, lexical, and conjunction. The first three types fall under the category of grammatical cohesion. Lexical cohesion on the other hand refers to relations between any lexical item and a previously occurring lexical item in the text. Conjunctive cohesions are affected by the cohesion elements that are called conjunctives. Conjunctions are considered as grammatical devices with a lexical component. According to Halliday and Hasan, the presence of these cohesive devices is essential for building text cohesion. On the other hand, textuality and logical and semantic relations are negatively affected by the absence or inadequate use of cohesion. Hence, the whole text fails to meet the writer's expectations.

The next section below summarizes the Halliday and Hasan's (1976) cohesion taxonomy in a glance (see Halliday \& Hasan, 1976, pp. 274-292)

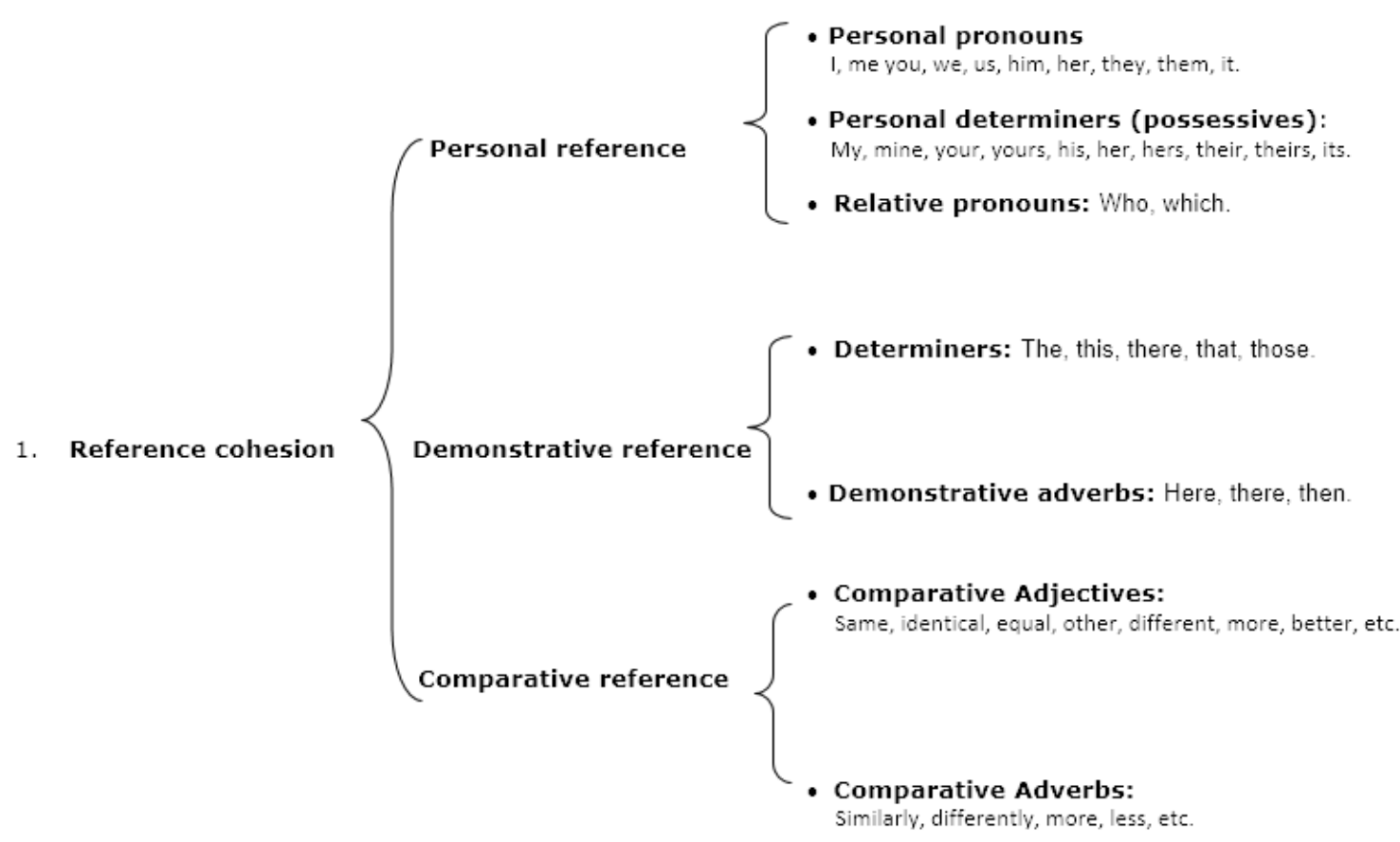


2. Substitution cohesion

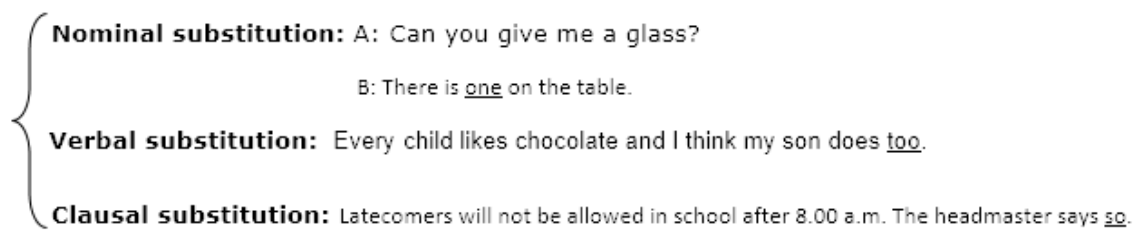

3. Ellipsis $\left\{\begin{array}{l}\text { Nominal ellipsis: These are my two dogs. I used to have four. } \\ \text { Verbal ellipsis: Teacher: Have you done the homework? John: Yes, I have. } \\ \text { Clausal ellipsis: Mary: Are you going to buy a new dress for my birthday? Mother: Yes. }\end{array}\right.$

4. Conjunctive cohesion: Hence, so, after, and, but, then, etc. eg. He took a cup of coffee after he woke up.

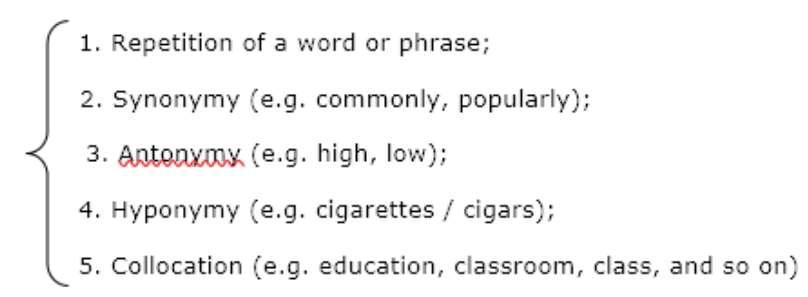

\section{Purpose of the Study}

The present study attempts to explore the attitudes of Kuwaiti undergraduate students of English towards the writing process in terms of quality and cohesion. It further investigates the students use of macro-level cohesion in their written products.

\section{Research Questions}

The study aimed to address the following research questions:

(1) What are the characteristics of the texts produced by Kuwaiti undergraduate students in terms of cohesion and quality?

(2) Is there a relationship between cohesive devices' measures and text evaluation scores?

\section{Methods}

The current study utilized a mixed methods design of both qualitative and quantitative research methodology, to analyze the participants' written products, since measurement is one of the quantitative methodology features, which will facilitate the researcher's goals in measuring the use and frequency of various types of cohesive devices in Kuwaiti EFL undergraduate students, as well as the quality of their writing. According to Mackey and 
Gas (2005), qualitative research provides a rich description that is not possible in quantitative methods. In addition, it takes into account certain behaviours that are specific to the context under study and not other contexts. In quantitative research, Creswell (2008) states that a quantitative study is an inquiry into an identified problem that is based on testing a theory using statistical techniques. Furthermore, the theory is composed of variables, measured by numbers, and analyzed by statistical measures, which determine whether the predicted generalizations are true or not. In addition, the results in quantitative research are less affected by the researcher's expectations, therefore, the results and procedures of the study in quantitative research can easily replicated by others, which will enhance its validity and reliability (Bryman, 2004).

\section{Participants}

The 128 participants voluntarily participated in the current research. They were from different majors studying English as a compulsory subject for academic purposes, who were enrolled in the first and second year of study in the department of English Language and Literature at Kuwait University, College of Arts. in the same. All the participants shared similar characteristics in terms of age (19 to 21), cultural background, and educational level.

\section{Instruments}

Written products were a significant element of the study. They provided more in depth understanding of the students' writing approaches and attitudes, and the quality of their writing in terms of generating a cohesive text, which helped to generate more questions about the problems those students of English encountered in their writing practices. Accordingly, the participants were required to compose a descriptive writing task. This tool was used to identify and analyze the content of their texts in terms of macro-level cohesion and quality. All participants were asked to compose in English and were given three alternative topics to choose from. The topics of the writing task were familiar ones which were close to the students' experience. These topics were chosen from a large number of alternatives that were supposed to be similar to the topics studied in class or assigned in exams. The titles were: (a) A memorable journey; (b) A frightening experience; (c) A trip that you would like to take. Write a paragraph about one of the topics provided. Accordingly, the written texts produced by the participants were assessed for quality according to Jacobs, Zinkgraf, Wormouth, Hartfiel, and Hughey (1981) criteria, which was considered as guidance for the process of scoring. The reason for adopting these criteria is their reliability which had led to their use by other researchers conducting similar studies. The main purpose of the scoring was to rank the performance of the students. Accordingly, the rank was relative to the standard test of Jacobs et al's (1981), that readers make five holistic assessments of the same essays. These assessments target different aspects of the 
composition: content (30 points); organization (20 points); vocabulary (20 points); language use (25 points); and mechanics ( 5 points), as shown in Table 4.2 below. Further, the individual scale and the overall summed scale are broken down into numerical ranges which correspond to four mastery levels: excellent to very good (83 - 100 points); good to average (63-83 points); fair to poor (52-63 points); and very poor (34-52 points).

\section{Data Collection and Analysis}

Students' texts were analyzed to investigate the most frequent and the least used cohesive devices students employ in their writing process. The written texts were scored based on the taxonomy of cohesive devices developed by Halliday and Hasan (1976). The researcher concentrated on dealing with the macro-level of cohesive devices, in order to shed light on the difficulties and problems in the students' writing process.

The presence and variation of cohesive devices (reference, lexical, conjunction, substitution, and ellipsis) were investigated, in order to discover the most frequent and the least-used devices students employ in their writing process. The data for this study was collected from compositions written by students during one session and were scored based on the taxonomy of cohesive devices developed by Halliday and Hasan (1976). Consequently, all five macro-level taxonomy of cohesive devices consisting of reference, substitution, ellipsis, conjunction and lexical cohesion were scored and coded in the 128 student texts. Each text was analyzed in terms of cohesion, providing a frequency count for each cohesive device. The frequency counts were normalized for text length and reported as frequency of the device per 100 words of text, in order to allow the researcher to compare cohesion counts in texts of different length.

\section{Results and Discussion}

In the current study, the researchers' intention was to provide the analysis of top level taxonomy of cohesive devices used in each text. This was based on the idea that Kuwaiti college students face difficulties in using proper cohesive devices in their writing, and this study is considered as an investigation of this problem. Accordingly, the cohesive devices were identified through the participants' writing and were counted manually by the researcher, and then the frequency, mean and standard deviation of the cohesive devices were verified using SPSS (Table 1). Correlation was also examined to determine the relationship between the frequency of the use of cohesive devices and the quality of the writing through scores (Table 2). 
Descriptive Statistics

\begin{tabular}{|c|c|c|c|}
\hline Type of Cohesive Device & Frequency & Mean & Std. Deviation \\
\hline Reference & 2897 & 21.3307 & 5.77440 \\
Conjunction & 755 & 5.6357 & 2.61611 \\
Lexical & 977 & 7.4274 & 3.31224 \\
Substitution & 61 & .4026 & .73380 \\
Ellipsis & 40 & .3029 & .67524 \\
\hline
\end{tabular}

Table 1: Data of the Normalized Count of the Cohesive Devices Used by the 128 Students

Descriptive statistics derived from the data are presented in order to investigate the most frequent cohesive devices which students implement in their written products. The five cohesive devices consisted of reference, substitution, ellipsis, conjunction and lexical cohesion were scored and coded in the 128 students' texts. The analysis was based on the normalized counts of the cohesive devices per 100 words in order to provide a clear picture of the length of the text and its relation to the number of cohesive devices employed by the students. With regard to the frequency count of the cohesive devices used by the 128 students of the three data sets shown in Table 1 above, it was evident that the students in the present study employed a variety of cohesive devices with some types of devices used more frequently than others.

As illustrated in the table above, the reference cohesive device was the most extensivelyused category of cohesion in the writing of all the 128 participants with a mean of 21.3307 $(S D=5.7744)$, followed by lexical cohesion that was used among 126 students with a mean of $7.4274(S D=3.3122)$, and then conjunction which was used among 124 students with a mean of 5.6357 ( $S D=2.6161)$. Substitution and ellipsis were used very rarely; substitution was used by only 39 students with a mean of $0.3029(S D=0.6752)$, while ellipsis was only used among 29 students with a mean of 0.3029 ( $S D=.6752)$. The standard deviation across the most frequently used cohesive devices is high, indicating that the devices are used to very different extents by different writers.

Consequently, correlation analysis was used to illustrate the strength and direction of the linear relationship among cohesive devices' measures and text evaluation scores. Table 2 below sets out the Pearson Correlation Coefficients of the various five dimensions of cohesive devices representing the moderate positive significance relationship with text evaluation scores. A $p$-value less than 0.05 was required for significance. The correlations among the writing scores and the different cohesive variables are demonstrated in Table 2. As indicated in the table below, the analysis reveals that the correlation coefficient between writing scores and reference cohesive device is positive and statistically 
significant, since only the reference was highly correlated with score $(r=.271, p<0.05)$. This indicates that reference is well-used by students in generating high scoring texts. In addition, the results show that the correlation coefficient between score and word count (text length) is positive and statistically significant $(r=.631, p<0.05)$. This might be related to the fact that high score texts tended to be longer, even though text length is not one of the evaluation criteria for the text quality measure. Moreover, the analysis reveals that the correlation coefficient between ellipsis and reference is positive and significantly correlated $(r=.220, p<0.05)$, even with the ellipsis cohesive device being represented within this data as rarely used. Additionally, only conjunctions and references were found to be negatively correlated $(r=-.225, p<0.05)$.

\begin{tabular}{|c|c|c|c|c|c|c|c|c|}
\hline \multicolumn{9}{|c|}{ Correlations } \\
\hline & & $\begin{array}{l}\text { Normalised } \\
\text { reference } \\
\text { per } 100 \\
\text { words } \\
\end{array}$ & $\begin{array}{c}\text { Nermalised } \\
\text { conjunction } \\
\text { per } 100 \\
\text { words } \\
\end{array}$ & $\begin{array}{l}\text { Normalised } \\
\text { lexical per } \\
100 \text { words }\end{array}$ & $\begin{array}{l}\text { Normalised } \\
\text { substitution } \\
\text { per } 100 \\
\text { words } \\
\end{array}$ & $\begin{array}{l}\text { Normalised } \\
\text { ellipsis per } \\
100 \text { words }\end{array}$ & $\begin{array}{l}\text { Word } \\
\text { Count }\end{array}$ & Score \\
\hline \multirow{3}{*}{$\begin{array}{l}\text { Normalised } \\
\text { reference per } \\
100 \text { words }\end{array}$} & $\begin{array}{c}\text { Pearson } \\
\text { Correlation }\end{array}$ & 1 & $-.225^{\circ}$ & -.073 & -.087 & $.220^{\circ}$ & .061 & $.271^{\prime \prime}$ \\
\hline & Sig. (2-tailed) & & .011 & .412 & .331 & .012 & .492 & .002 \\
\hline & $N$ & 128 & 128 & 128 & 128 & 128 & 128 & 128 \\
\hline \multirow{3}{*}{$\begin{array}{c}\text { Nermalised } \\
\text { conjunction per } \\
100 \text { words }\end{array}$} & $\begin{array}{l}\text { Pearson } \\
\text { Correlation }\end{array}$ & $-.225^{\circ}$ & 1 & .117 & .004 & -.096 & -.025 & -.058 \\
\hline & Sig. (2-tailed) & .011 & & .190 & .967 & .282 & .783 & .516 \\
\hline & $N$ & 128 & 128 & 128 & 128 & 128 & 128 & 128 \\
\hline \multirow{3}{*}{$\begin{array}{l}\text { Nermalised } \\
\text { lexical per } 100 \\
\text { words }\end{array}$} & $\begin{array}{c}\text { Pearson } \\
\text { Correlation }\end{array}$ & -.073 & .117 & 1 & .065 & -.139 & -.108 & -.094 \\
\hline & Sig. (2-tailed) & .412 & .190 & & .466 & .118 & .224 & .290 \\
\hline & $N$ & 128 & 128 & 128 & 128 & 128 & 128 & 128 \\
\hline \multirow{3}{*}{$\begin{array}{l}\text { Normalised. } \\
\text { substitution } \\
\text { per } 100 \text { words }\end{array}$} & $\begin{array}{c}\text { Pearson } \\
\text { Correlation }\end{array}$ & -.087 & .004 & .065 & 1 & .087 & .140 & .033 \\
\hline & Sig. (2-tailed) & .331 & .967 & .466 & & .328 & .115 & .710 \\
\hline & $N$ & 128 & 128 & 128 & 128 & 128 & 128 & 128 \\
\hline \multirow{3}{*}{$\begin{array}{l}\text { Nermalised } \\
\text { ellipsis per } \\
100 \text { words }\end{array}$} & $\begin{array}{c}\text { Pearson } \\
\text { Correlation }\end{array}$ & $.220^{\circ}$ & -.096 & -.139 & .087 & 1 & -.018 & .166 \\
\hline & Sig. (2-tailed) & .012 & .282 & .118 & .328 & & .840 & .061 \\
\hline & $N$ & 128 & 128 & 128 & 128 & 128 & 128 & 128 \\
\hline \multirow[t]{3}{*}{ Word Count } & $\begin{array}{c}\text { Pearson } \\
\text { Correlation }\end{array}$ & .061 & -.025 & -.108 & .140 & -.018 & 1 & $.631^{\prime \prime}$ \\
\hline & Sig. (2-tailed) & .492 & .783 & .224 & .115 & .840 & & .000 \\
\hline & $N$ & 128 & 128 & 128 & 128 & 128 & 128 & 128 \\
\hline \multirow[t]{3}{*}{ Score } & $\begin{array}{c}\text { Pearson } \\
\text { Correlation }\end{array}$ & $271^{*}$ & -.058 & -.094 & .033 & .166 & $.631^{*}$ & 1 \\
\hline & Sig. (2-tailed) & .002 & .516 & .290 & .710 & .061 & .000 & \\
\hline & $N$ & 128 & 128 & 128 & 128 & 128 & 128 & 128 \\
\hline \multicolumn{9}{|c|}{ *. Correlation is significant at the 0.05 level (2-tailed). } \\
\hline & 8001 & tailed). & & & & & & \\
\hline
\end{tabular}

Table 2.: Correlation of Cohesive Devices' Measures and Text Evaluation Scores 


\section{Implication to Research and Practice}

This study provided implications for L2 writing instruction, which may offer suggestions and recommendations for writing course designers in Kuwait in the light of the data obtained using the research instruments. For example, cohesive devices seem not to have received as much attention as they deserve in the classroom, although they have a significant role in the writing process. Considering the lack of explicit focus, Liu and Braine (2005) suggest that the remedial action is that "focused activities should be developed in combination with explicit instruction" (p.634). In this way, students can become more aware of the importance of cohesive devices in accomplishing the writing task and consequently use them effectively and appropriately. The study findings would suggest that cohesive devices are used to varying degrees with frequent use of references and lexical cohesion but rare use of other devices. Therefore, explicit instruction with examples as well as focused activities on using different cohesive devices should be provided and developed by the writing teachers at an earlier stage in students' education, as should be trained on the use of cohesive devices that they tend to avoid in their writing, such as conjunctions, substitution, and ellipsis.

\section{Conclusion}

The present research was designed to provide answers to the research questions, to meet the research goals and objectives. Halliday and Hasan's (1976) cohesion framework was adopted to analyze Kuwaiti undergraduate students' use of cohesive devices. The data of the study was quantitatively analyzed through identifying the frequency and the types of cohesive devices used by the participants, and by evaluating the overall quality of the students' written products. According to the results presented in the current research, there was a notable difference in the students' use of cohesive devices in terms of frequency and variety. Students overused certain types of cohesive devices (reference, conjunction, and lexical) while neglecting to use the others (substitution and ellipsis). This is certainly caused by lack of competence in their use of cohesive devices. The analysis also revealed that the correlation coefficient between writing scores and reference cohesive device is positive and statistically significant, since only the reference.

This study has shown the difficulty Kuwaiti undergraduate students of English face in their English descriptive writing, and their attitudes towards the writing process.

\section{Future Research}

This study focused on first and second year undergraduate students. Other researchers can investigate the type of cohesive devices used by other ESL student writers. This can provide a more comprehensive picture of the problem under study. Moreover, future 
studies may investigate the micro level cohesive devices, which would shed more light on the issue addressed in the present study. Such work could contribute significantly to EFL language curricula in Kuwait

\section{References}

Al-Hibir, I. B. \& Al-Taha, F. (1992). An analysis of Orthographic errors made by Saudi university students learning English. Language Learning Journal, 5 (1), 85-87.

Halliday, M.K. \& Hasan, R. (1976). Cohesion in English. London: Longman.

Ahmed, A. (2010). Students' problems with cohesion and coherence in EFL essay writing in Egypt: Different perspectives. Literacy Information and Computer Education Journal (LICEJ), 1 (4), December 2010.

Rogers, H. (2005). Writing Systems: A Linguistic Approach. Oxford: Blackwell.

Chakraverty, A., \& Gautum, K. (2000). Dynamics of writing. Forum, 38 (3).

Shokrpour, N. \& Fallahzadeh, M. (2007). A survey of the students and Interns' EFL writing problems in Shiraz University of Medical Sciences. Asian EFL Journal, 9 (1).

Kharma, N. \& Hajjaj, A. (1989). Errors in English among Arabic speakers: Analysis and remedy. Essex: Longman.

Rao, Z. (2007). Training in brainstorming and developing writing skills. ELT Journal, 61 (2).

Fageeh, A. (2003). Saudi college students' beliefs regarding their English writing difficulties. Unpublished Ph.D. thesis. Indiana University of Pennsylvania, USA.

Taher, H. (1999). Cohesion and Coherence of the academic texts written by Yemeni learners. Unpublished Ph.D. these. University of Birmingham, UK.

Abd. El.Motaal, M. (2001). The effectiveness of a remedial unit for teaching some writing errors of the secondary school studies. Thesis submitted for the degree of M.A. in education. Mansura University, Egypt. Hinkel, E. (2004). Rhetorical Features of Text: Cohesion and Coherence, Teaching Academic ESL Writing: Practical Techniques in Vocabulary and Grammar. Lawrence Erlbaum Associates, Mahwah, New Jersey, pp. 265.

Connor, U. (1996). Contrastive Rhetoric: Cross-cultural Aspects of Second Language Writing. Cambridge: CUP.

Qaddumi, M. (1995). Textual Deviation and coherence problems in the writings of Arab students at the University of Bahrain: Sources and solutions. Ph.D. dissertation, University of Nottingham, UK.

Creswell, J. W. (2008). Educational Research: Conducting, and evaluating quantitative and qualitative research, ( $3^{\text {rd }}$ ed.). Peason Prentice Hall: University of Nebraska Press. 
Bryman, A. (2004). Social research methods. Oxford University Press: Oxford.

Liu, Meihua \& Braine, G. (2005). Cohesive features in argumentative writing produced by Chinese undergraduates. System, 33 (4), 623-636.

Jacobs, H. L., Zinkgraf, S.A., Wormouth, D.R., Hartfield, V.F., \& Hughey, J.B. (1981). Testing ESL composition: A practical approach. Rowely, MA: Newbury House.

Mackey, A., Gas, S. (2005). Second language research: Methodology and design. Lawrence Erlbaum Associates, Inc.: New Jersey. 